\section{Til middag hos Werner Best}

\author{
AfGunnar Larsen, Minister for offentlige \\ Arbejder 1940-43
}

\section{Udgivers forord:}

Minister for offentlige arbejder, direktør Gunnar Larsen, der juli 1940 var blevet medlem af en samlingsregering under Thorvald Staunings ledelse, begyndte i januar 1941 at føre dagbog. Næsten dagligt dikterede han dagbogen i over $21 / 2$ år til september 1943, så der i dag foreligger et maskinskrevet manuskript på ca. 2500 sider. $\mathrm{Om}$ årsagen til at den travle erhvervsmand og minister afsatte tid til et sådant projekt, kan der kun gisnes. Gunnar Larsen har ikke givet nogen direkte forklaring derpå, men dagbogen er i sig selv måske den allerbedste forklaring. I de politisk ustabile og uforudsigelige tider har han villet fastholde væsentlige forhold, som han blev involveret i eller var vidne til. Det var bestemt ikke alle de for sam- og eftertid relevante tildragelser, han beskæftigede sig med, han betroede til papiret, men det er hverken heller at forvente eller forlange. Alligevel er det ved siden af P. Munchs erindringer og optegnelser fra besættelsen den væsentligste enkeltkilde til oplysning om tidens politiske forhold. Gunnar Larsens udførlige referater af f. eks. ministermøderne er i reglen langt mere oplysende end de samtidigt førte ministermødeprotokoller, og så giver dagbogen nogle af de mange detaljer, karakteristikker og beskrivelser af ydre forhold, som bringer læseren i en forbindelse med tiden.

Her skal bringes et eksempel på, hvilken rigdom af oplysninger, hvilket rum og miljø, dagbogen med ét slag kan bringe læseren med ind i. Tiden er 2. april 1943. Gunnar Larsen skulle med sin kone Kirsten til middagsselskab hos den tyske rigsbefuldmægtigede i Danmark, Werner Best. Best og frue havde indrettet sig i den store villa "Rydhave" ved Strandvejen. Best havde afløst Cecil von Renthe-Fink på denne post $\mathrm{i}$ november 1942 og var stadig forholdsvis ny i Danmark, men havde allerede udført sine politiske svendestykker: Medvirket til en hurtig ny dansk regeringsdannelse i november 1942 under Erik Scavenius' ledelse, bragt de danske nazister under Frits Clausens ledelse ud på et sidespor og havde fået afholdt folketingsvalg i marts 1943. Alt som led i den overvågningsforvaltning, som han mente tjente tyske interesser bedst, da den bandt færrest mulige af besættelsesmagtens ressourcer. Det var en mand med politisk succes, Gunnar Larsen med frue skulle på besøg hos i begyndelsen af april.

Selskabeligheden tjente naturligvis et politisk formål, og det var for de besøgende om at gætte, på hvilke områder værten i løbet af aftenen ville vælge sine dagsordener. Det fremgår af Gunnar Larsens beskrivelse af middagen ret klart, hvor Best ville hen - $\mathrm{i}$ hvert fald som Larsen opfattede det. Foruden at udbrede sine politiske ideer og egne fortræffeligheder og skabe opbakning bag førstnævnte, havde Best bl.a. et konkret problem, som han ville prøve at få løst gennem Gunnar Larsen, hvad enten det skulle være i Larsens egenskab af direktør eller minister for offentlige arbejder. Det drejede sig om den af DNSAP oprettede Landsarbejdstjeneste, som Best nu stod med finansieringen af, efter at Frits Clausen havde opgivet den tyske økonomiske støtte efter valget. Kunne Larsen på en eller anden måde overtage foretagendets medlemmer, var Best et problem foruden. 
Desværre mangler der to sider i dagbogen på dette sted, netop som denne drøftelse begynder, så hvordan Gunnar Larsen verbalt har reageret, er uvist, men i hvert fald var det ikke et foretagende, han siden beskæftigede sig med. Da teksten begynder igen, kommer læseren lige ind midt i referatet af samtalen om de omfattende tyske befæstningsarbejder i Danmark og deres betydning for konkurrencen om arbejderne og dansk erhvervsliv. På dette tidspunkt var Best og Gunnar Larsen igen vendt tilbage til det øvrige selskab, som Gunnar Larsen startede med at præsentere, så flere stemmer bidrog til drøftelsen. Det fremgår blandt meget andet heraf, hvor stor betydning de tyske tilstedeværende lagde på den danske landbrugseksport til Tyskland.

Dagbogen er under udgivelse ved lektor, ph.d. Joachim Lund og undertegnede. Kommentarerne til teksten er i noterne indskrænket til et minimum og alene de steder, hvor den er særligt påkrævet. Dagbogen er i privateje, men udlånt til Det Kongelige Bibliotek i forbindelse med udgivelsesarbejdet. På Rigsarkivet findes en kopi, som har været stillet til rådighed for forskningen gennem en årrække. Enkelte mindre uddrag af dagbogen er trykt i Den parlamentariske Kommissions Betænkning bd. 4 og 10. Til udgivelsesarbejdet er modtaget støtte fra Kulturministeriets forskningspulje.
Direktør Gunnar Larsen var kendt som en moderne erhvervsmand, da han 38 ar gammel blev medlem af Staunings samlingsregering 8. juli 1940. Han blev som minister for offentlige arbejder straks beskyldt for at varetage privatøkonomiske interesser. Kritikken kom fra det yderste hojre og det yderste venstre. Den 14. september 1941 indviedes et af tidens store anlogsprojekter, den såkaldte fugleflugtslinje, en motorvejs-og togforbindelse mellem Lübeck og Kobenhavn over Femer Balt. Gunnar Larsen tog det forste spadestik - og spaden knakkede. Det er blevet et beromt billede - afen senere tid gjort til symbol $p a$ et tvivlsomt dansk-tysk samarbejde (Det Kongelige Bibliotek).

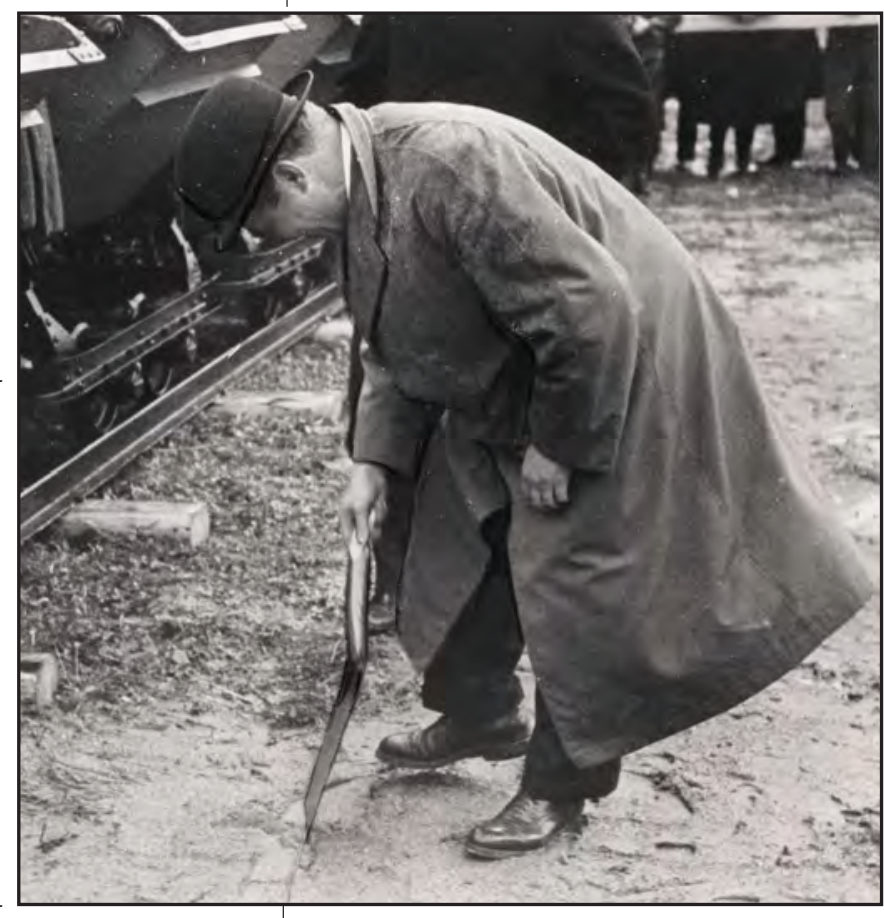




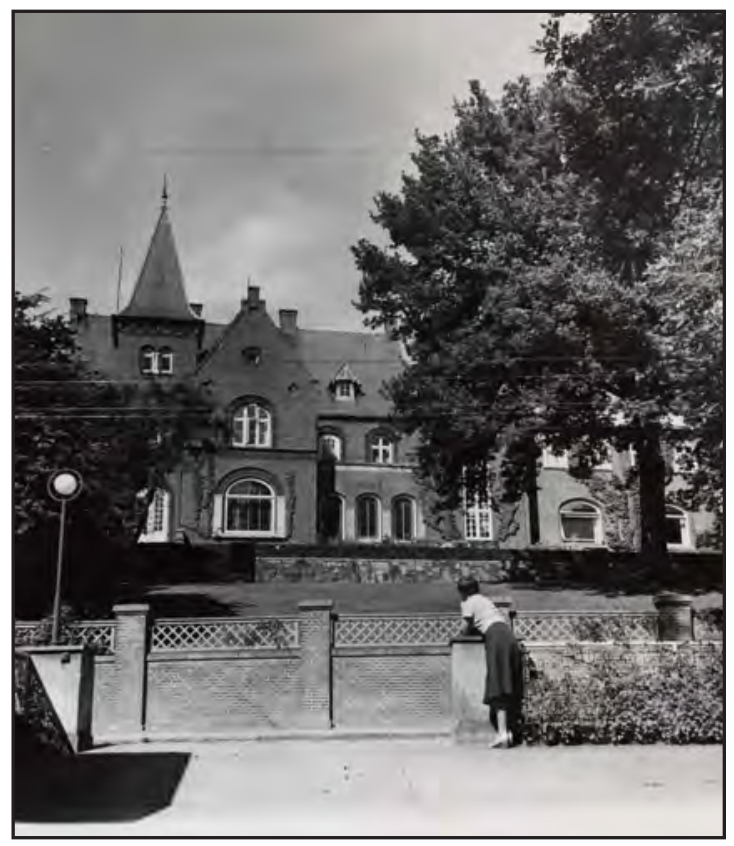

For at den nye tyske rigsbefuldmagtigede Werner Best kunne bo standsmassigt, købte den danske stat den store villa "Rydhave" ved Strandvejen $i$ Kobenhavn som hans embedsbolig. Villaen blev udstyret med indbo efter fru Bests ønske, ligeledes betalt af den danske stat (Det Kongelige Bibliotek).

\section{Fredag den 2. April 1943}

Kl. 19 var Kirsten og jeg til Middag hos Dr. Best og Frue i deres nye Hjem paa Strandvejen. Af andre Danskere var der kun Afdelingschef Wassard og Generaldirektør Knutzen. Fra tysk Side deltog Dr. Walter, Dr. Ebner og Legationssekretær Duckwitz med Frue samt Generalkonsul Krüger med Frue. Desuden var den svenske Gesandt von Dardel med Frue til Stede. Ved Middagen, som var nydelig uden paa nogen Maade at være overdaadig, sad jeg paa Fru Bests højre Side og havde Fru Generalkonsul Krüger paa min højre Haand.

Med Hensyn til selve Hjemmet skal det bemærkes, at dette i høj Grad bærer Præg af at være udstyret meget hastigt ved tilfældigt Sammenkøb; det savnede fuldstændigt personligt Præg, og Dagligstuen, som vi sad i efter Middagen, og som iøvrigt havde en meget smuk Beliggenhed med en pragtfuld Udsigt over Sundet, kunde lige saa godt have været en almindelig Modtagelsessalon i ethvert internationalt Hotel. Det skal dog bemærkes, at Bests endnu ikke havde faaet deres egne Ejendele herop. Sidst jeg var sammen med Fru Dardel - jeg tror det var hos den italienske Gesandt - spøgte hun med, at hun næste Gang, hun traf Dr. Best, vilde tvinge ham til at tale enten Engelsk eller Fransk, idet hun vistnok havde $\mathrm{Haab}$ om, at han ligesom Tysk overfor Personer, der overhovedet kunde udtrykke sig paa Tysk. Denne lille Spøg lykkedes imidlertid ikke for Fru Dardel, jeg sad lige overfor hende ved Bordet, og hun slog straks ind paa Fransk; imidlertid svarede Dr. Best straks paa Fransk uden at protestere og gennemførte uden større Vanskelighed en Konversation paa Fransk, hvad der efterhaanden førte til, at 

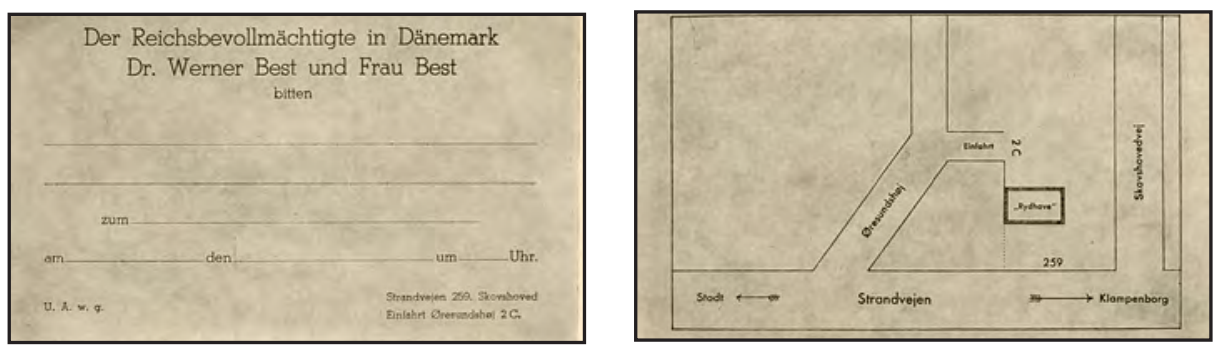

Den formelt korrekte Best lod fortrykke indbydelser, så gaster let kunne finde frem til villa "Rydhave." Rydhave er $i$ dag den amerikanske ambassadors embedsbolig.

de ganske naturligt uden noget som helst Pres fra Dr. Bests Side atter faldt tilbage til Tysk. ${ }^{1}$ Episoden er naturligvis yderst ringe og har ingen Betydning, men den viser igen Dr. Bests langt større Smidighed og Facilitet sammenlignet med Renthe-Fink, der iøvrigt $\mathrm{i}$ Modsætning til Dr. Best talte et fortræffeligt Engelsk og Fransk. - Iøvrigt var Forholdet mellem Dardel og Best yderst hjerteligt og venskabeligt; der var intet at observere udover de selskabelige Former. Ogsaa Fru Best optraadte i alle Maader som en særdeles hensynsfuld og god Værtinde.

Kort efter Middagen anmodede

Dr. Best mig om at faa en Samtale med mig, og vi sad $i$ en halv Time eller tre Kvarter alene i et Hjørne. Dr. Best begyndte med en Gennemgang af alle de Fejl, der var begaaet fra tysk Side med Hensyn til den danske indrepolitiske Situation og i Særdeleshed med Henblik paa de danske Nationalsocialister. Dr. Best udtalte, at det, der var sket ved Valget, havde han i Forvejen forudset. Han var klar over, at Landet laa saaledes, som Valget viste, og havde derfor lagt meget Vægt paa, at dette blev konstateret, uanset at han i Berlin havde mødt meget stor Modstand, fordi man der fra visse Kredse var af den Opfattelse, at Dr. Best ikke havde Ret. Han havde imidlertid insisteret paa, at Valget skulde føres igennem, fordi han fandt, at det fra et politisk Synspunkt paa langt Sigt var det eneste rig- tige. I denne Forbindelse gjorde han opmærksom paa, at han var fuldstændig klar over, at man havde fort en helt forkert Politik fra tysk Side overfor Frits Clausen. Skylden for Frits Clausens daarlige Propaganda og hele hans daarlige, politiske Standing kunde ikke udelukkende lægges paa Frits Clausen og hans danske Raadgivere, men man havde fra tysk Side forsyndet sig alvorligt, bl. a. ved at give Frits Clausen et helt forkert Indtryk af den Støtte man kunde tænke sig at give ham i visse givne Situationer.

I Forbindelse hermed kom vi ogsaa ind paa en Diskussion af Renthe-Finks Stilling, og Dr. Best var tilbøjelig til at lægge en ikke uvæsentlig Del af Skylden paa Renthe-Fink, fordi denne havde været for svag. Han erklærede dog, at Renthe-Fink her havde haft en meget vanskelig Position, fordi man i Berlin fra visse partipolitisk indflydelsesrige Personers Side havde været indstillet paa saa kraftigt som muligt at tvinge Frits Clausen frem gennem tysk Intervention. Dr. Best nævnede ingen Navne, men jeg maatte faa det Indtryk, at han refererede til Luther og Konsorter. ${ }^{2}$ Dr. Best stod derimod meget starkt, fordi han partipolitisk var uafhangig, saaledes at han ikke behøvede at rette sig efter von Ribbentrop. Han havde ikke bedt om at faa Stillingen i Danmark, man havde tværtimod sendt Bud efter ham, og hvis det kom til et endeligt Brud mellem ham og von 


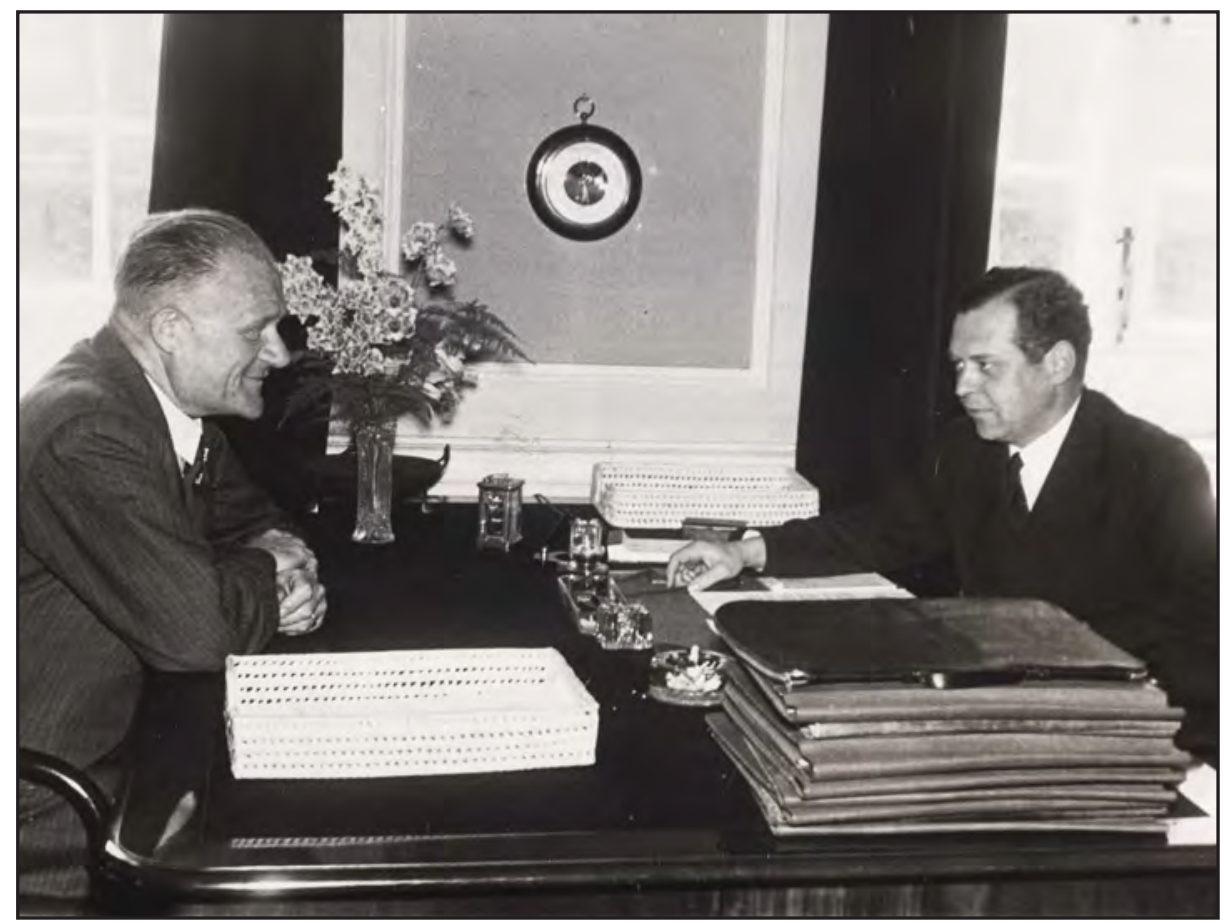

Gunnar Larsen blev med tiden en af regeringens mest upopulare ministre sammen med justitsminister E. Thune Jacobsen, begge kun overgået af Erik Scavenius. Upopulariteten hang sammen med det meget synlige samarbejde, som en minister for offentlige arbejder ikke kunne komme uden om. Her er Gunnar Larsen (t.h.) fotograferet i selskab med en anden mindre popular skikkelse, DSB's generaldirektør P. Knutzen (Det Kongelige Bibliotek).

Ribbentrop, saa stod han saaledes, at han altid kunde gaa over til en anden Stilling andre Steder, som var ligesaa betydningsfuld, men som ikke var underlagt Auswärtiges Amt. Han behøvede derfor ikke at bøje sig for von Ribbentrop, og dette var Grunden til, at Valget var blevet ført igennem. ${ }^{3}$

$\mathrm{Nu}$ efter at Valget havde fundet Sted, og Frits Clausen var blevet klar over, at han ikke kunde vente at blive pousseret frem ved Hjælp af tyske Bajonetter, havde han draget Konsekvensen af Situationen, og var nu indstillet paa at indskranke den store Facade og kun fore en ren systematisk Partipolitik paa normal Vis i det smaa, og det skulde saa vise sig, om han herigennem kunde skabe sig en Position. Det var Meningen, at Kontoret i Rosenvænget helt skulde ophøre, og Frits Clausen skulde saa holde sig til Bovrup. ${ }^{4}$

I Samtalens Løb kom vi ogsaa ind paa Frits Clausens Person, og jeg refererede her en Samtale, jeg en Gang for lang Tid siden havde haft med Dr. Dräger, hvor baade Dr. Dräger og jeg var enige om, at Frits Clausens Personlighed var alt for lille til en Opgave som den, han havde paataget sig, og som man i visse tyske Kredse mente, at han skulde kunne paatage sig, nemlig den at være Fører for et fremtidigt nationalsocia- 
listisk Parti i Danmark. Dr. Dräger og jeg var den Gang enige om, at Tyskerne aldrig vilde have bedømt Frits Clausen til at have tilstrækkelig stor Personlighed til at være Gauleiter, og saa kunde man da heller ikke regne med, at han skulde have tilstrækkelig Personlighed til at være en tilstrækkeligt fremstaaende politisk Fører i Danmark. ${ }^{5}$ Dette var Dr. Best fuldstændig enig i. Han udtalte i denne Forbindelse, at dette var sørgeligt, for man maatte jo indrømme, at Frits Clausen var gaaet ind for den nationalsocialistiske Ideologi paa et meget tidligt Tidspunkt, hvor han tilsyneladende ikke kunde gøre sig Forventning om at komme til at slaa igennem, men han havde dog kæmpet Kampen paa et idealistisk Grundlag, og det var derfor sørgeligt, at han viste sig at være for lille en Mand til Opgaven, naar der endelig viste sig en Chance i Horisonten. $\mathrm{Nu}$ stod man i den beklagelige Situation, at Frits Clausen og hans Parti, der netop havde kæmpet for den tyske Ideologi, i Virkeligheden stod som den store Anstødssten for en Tilnærmelse og Forstaaelse mellem det danske politiske Liv og det tyske. Han udtalte, at dette var ,eine grosse Tragödie“, men det fik nu være, hvad det vilde. Man maatte se Situationen i Øjnene, saaledes som den virkelig forelaa, og det var det, Dr. Best nu gjorde, ligesom han ogsaa mente, at Frits Clausen nu var klar over sin Stilling. Iøvrigt bemærkede han om Frits Clausens Person, at han jo ganske manglede Selvdisciplin. Det var usømmeligt, at en Mand, som selv var Læge, tillod sig at komme til at se saa fed og uappetitlig ud, som Frits Clausen gør. Det kunde en Førerskikkelse ikke tillade sig.

I Samtalens Løb udtalte jeg flere Gange, at jeg havde varet vant til overfor Renthe-Fink at tale meget frit ud om Forholdene, ogjeg havde Gang paa Gang foreholdt ham, at man efter min Mening forte en helt

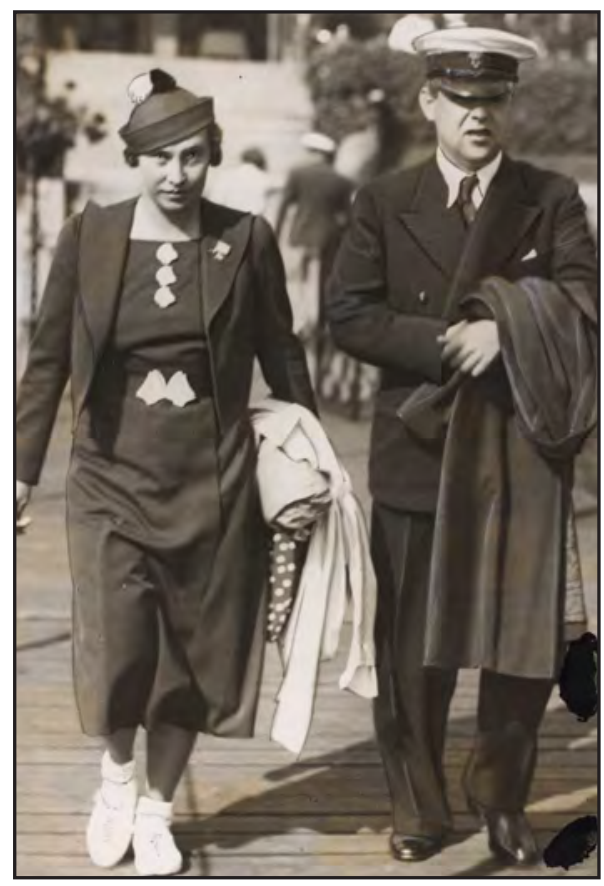

Gunnar Larsen fotograferet med sin hustru, Kirsten Larsen. Gunnar Larsens ministertid kom til at betyde en voldsommere andring $i$ hans og familiens liv, end det var til at forudse i 1940. Efter en hetz $i$ den illegale presse måtte han august 1944 rejse til Sverige, og efter maj 1945 sad han 11 måneder i fangsel for siden af at blive frikendt for alle anklager. Da var hans tilvarelse i Danmark umulig, og familien bosatte sig i Irland. Gunnar Larsen dode 1973 (Det Kongelige Bibliotek).

\section{forkert Politik fra tysk Side med Hensyn til} Frits Clausen. Jeg var imidlertid altid blevet mødt med det Argument, at det kunde nu ikke være anderledes, for Berlin ønskede det paa den af Renthe-Fink angivne Maade.

Dr. Best kom herefter ind paa Frikorpset, og udtalte ogsaa her, at man fra tysk Side havde grebet ved Siden af, ved at man gjorde det til et partipolitisk Apparat og ved at fore det over paa Frits Clausens Parti. Man skulde have holdt det udelukkende 


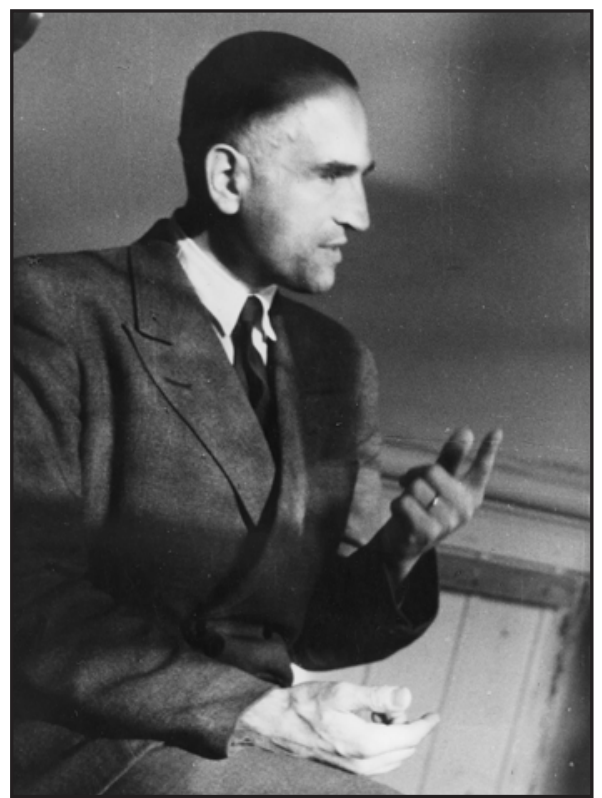

Werner Best fotograferet uden SS-uniform efter maj 1945, da han skulle forklare og forsvare den af ham forte politik i Danmark november 1942maj 1945. En dødsstraf ved Københavns Byret blev andret til fangsel, og Best kunne forlade Danmark som en fri mand 29. august 1951 (Det Kongelige Bibliotek).

paa Kampen mod Kommunismen og Vaabenbroderskabet med Finland. Havde man gjort dette, vilde man efter Dr. Bests Mening i højere Grad have faaet langt videre Kredse i Tale, end Tilfældet nu var, men ogsaa dette var en Fejl, der nu var yderst vanskelig at redressere. Iøvrigt skulde Martinsen nu organisere en ny Hvervekampagne, som udelukkende skulde bygges paa en Appel til Befolkningen paa Basis af det rent racemæssige og Kampen mod Bolsjevismen, altsaa en fuldstændig Frigørelse fra Frits Clausen. ${ }^{6}$ Jeg udtalte, at det kunde være meget godt, men at man ikke maatte vente sig særlig meget heraf som Følge af Fortidens Synder. Dette forstod Dr. Best meget vel.
Med Hensyn til Martinsen bemærkede Dr. Best, at han overhovedet ikke var Politiker eller havde politiske Ambitioner. Han var kun slet og ret Soldat i Modsætning til von Schalburg, som havde været politisk interesseret, og som maaske kunde have været anvendt som en Afløser af Frits Clausen.? Efterhaanden drejede Samtalen hen paa det Emne, som Dr. Best i Virkeligheden ønskede at tale med mig om. Dette var følgende: Efter at man nu havde isoleret Frits Clausen og reduceret ham til den Stilling, hvor han hørte hjemme, var der visse Poster i Fallitboet, som man maatte se at faa disponeret over. Hertil hørte blandt andet Fadrelandet, i hvilken Henseende han havde gjort sig visse Betragtninger, men der forelaa endnu ingen Afgørelse om, hvad man vilde foretage sig med Bladet. ${ }^{8}$ Imidlertid var der en anden Post, der var vanskelig at faa afviklet, og som ligesom Fadrelandet betød en vis Prestige for tyske Interesser. Det var Spørgsmaalet om Arbejdstjenesten. Arbejdstjenesten var jo en Del af det store Program indenfor Partiideologien, og man havde derfor i sin Tid støttet Frits Clausen ogsaa paa dette Punkt, idet man havde sendt en 60-70 Personer til Tyskland, hvor de var blevet oplart indenfor Reichsarbeitsdienst. Dette var naturligvis sket paa tysk Bekostning, og nu stod man overfor at skulle afgøre, hvad man skulde stille op med disse Folk, naar det national-socialiske Partis Organisation skulde reduceres, idet der da ikke var Plads til dem indenfor Rammerne, og man faktisk havde paataget sig visse moralske Forpligtelser overfor disse Mennesker, ligesom man ogsaa havde en Prestige i Klemme - ikke mindst overfor de ledende indenfor Reichsarbeitsdienst i Tyskland. Dr. Best vilde derfor gerne spørge, om jeg ikke mente, at jeg under en eller anden Form kunde tonkes at ville interessere migfor Organisationen afen frivillig 


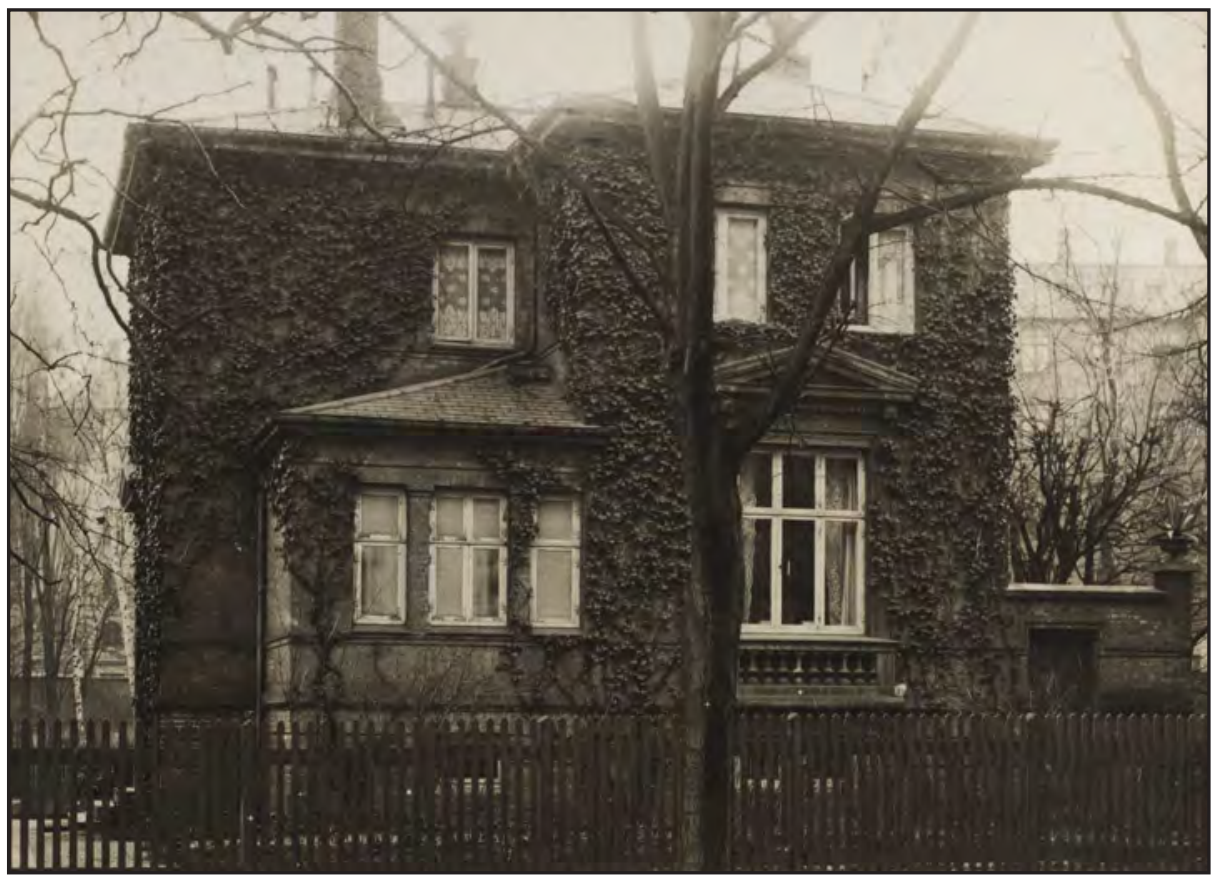

Takket vare betydelig tysk økonomisk støtte kunne DNSAP fra april 1941 oprette stabskontorer på Østerbro $i$ Kobenhavn ved siden afpartiets hovedkontor i Bovrup. Det varede til kort efter Werner Bests ankomst til Danmark. Best satsede helt og fuldt på den siddende regering under Erik Scavenius og ønskede at eliminere DNSAP. I konsekvens heraf og et skuffende valgresultat i marts 1943, opgav Frits Clausen videre økonomisk støtte fra besattelsesmagten. Det betød også at stabskontorerne med øjeblikkelig virkning blev opgivet (Det Kongelige Bibliotek).

- med stor Betoning affrivillig-Arbejdstjeneste i Danmark. Han var vidende om, at der inden Besættelsen i store danske Kredse, ogsaa indenfor Ingeniørernes Kreds, havde været en betydelig Interesse for Oprettelsen af en frivillig Arbejdstjeneste i Danmark. Hvis det nu var muligt at organisere en upolitisk Arbejdstjeneste, tænkte Dr. Best sig Muligheden af, at man efterhaanden indenfor Rammerne af en saadan Organisation kunde opsluge de 60-70 Mand, som man nu fra tysk Side havde en vis Prestige i...

[her mangler to sider i manuskriptet] ... for Tyskland, men iøvrigt var man fra dansk Side klar over, at naar det drejede sig om nødvendige militære Anlæg, hvis militære Betydning man naturligvis fra dansk Side ikke kunde give sig ud for at have nogen Mulighed for at bedømme, var dette Spørgsmaal set med tyske Øjne maaske af underordnet Betydning. En saa voldsom Aktivitet, som de 350 Millioner Kroner vilde betinge, rummede imidlertid ogsaa Farer paa andre Punkter, som maaske var af endnu større Betydning for Danmark og Tyskland, nemlig Virkningen paa Arbejdsmarkedet, idet man maatte forudse, at man i Danmark uanset det nye tyske Byggeprogram vilde faa Arbejdermangel til Foraaret 
paa Grund af Landbrugets og Brændselsproduktionens Behov. Vi regnede med i den kommende Sæson at skulle producere ca. 6 Millioner Tons Tørv foruden den store Brunkulsproduktion, og dette var jo en væsentlig Aflastning for de tyske Brændstofleverancer, ligesom det tjente til at opretholde det danske Erhvervsliv, hvilket man fra tysk Side maatte lægge stor Vægt paa. Hvis man uanset disse farlige Konsekvenser, som ogsaa i høj Grad vilde gaa ud over Tyskerne, idet man maatte forudse, at Landbrugsproduktionen vilde komme til at lide, hvorved Landbrugseksporten vilde gaa ned, ligesom det vilde medføre et stærkt Pres fra dansk Side for at faa Brændstoffer, alligevel af tvingende militære Grunde saa sig nødsaget til at gennemføre Programmet, henstillede Wassard, at man da fik det hele ordnet og organiseret fra Centralorganisationernes Side, baade hvad angaar Danskerne og Tyskerne, idet man ellers let kunde komme ud for, at hver enkelt Underorganisation eller Byggeplads vilde gaa ud i en vild Konkurrence om Arbejdskraft med en voldsom Overbydning ad den ene eller den anden Vej, som man fra hverken dansk eller tysk Side kunde kontrollere, med mindre alt blev fastlagt helt oppe fra Toppen. Blev dette ikke gjort, vilde det faa en endnu mere katastrofal Virkning for den danske Produktion til Skade ogsaa for Tyskland. Jeg støttede naturligvis Afdelingschef Wassard i hans Argumenter paa bedste Maade, men kunde iøvrigt paa disse Punkter kun tilføje meget lidt til det, Wassard havde udtalt. Baade Generaldirektør Knutzen og jeg gjorde imidlertid opmærksom paa, at der jo ogsaa i høj Grad var et Transportproblem med $i$ Spillet, og at Byggeprogrammet vilde belaste det danske Transportsystem paa en saadan Maade, at alt andet vilde blive blokeret, hvilket igen vilde være til stor Skade baade for danske og tyske vitale Interesser. Iøvrigt gjorde baade Generaldirektør Knutzen og jeg opmærksom paa, at ingen af os troede det muligt for det danske Transportsystem overhovedet at overkomme de Materialeleverancer, der her vilde komme paa Tale, ikke alene paa Grund af Mangel paa Transportmateriel, Vogne o. lign., men ogsaa fordi de fysiske Evner paa Endestationerne og Smaabanerne slet ikke kunde overkomme at udlade alt det Gods, der her var Tale om.

Dr. Best udtalte, at man fra tysk Side i høj Grad havde fælles Interesser med det danske Erhvervsliv og det danske, økonomiske Liv. Tyskland kunde ikke vare uinteresseret $i$, hvorledes det gik med den danske Krone. De besatte Landes Valuta kunde ikke undgaa at paavirke Tysklands egen Finanspolitik, og man var derfor i høj Grad interesseret $i$ at opretholde et sundt Pengesystem alle Vegne. Han erklærede, at han selvfølgelig ikke kunde udtalte sig om den militære Nødvendighed af de paagældende Anlæg, men var indforstaaet med, at Sagen blev forelagt et højere Forum i Berlin, for hvilket man da ogsaa maatte trække alle Konsekvenserne op. Dr. Walter udtalte, at ogsaa han saa med Ængstelse paa Situationen, og det kunde ikke fragaas, at en voldsom Udskrivning af Arbejdskraft vilde paavirke det danske Landbrugs Ydeevne, hvilket vilde sige, at den for Tyskland saa livsvigtige Landbrugseksport fra Danmark vilde komme til at dale. Det maatte derfor tilkomme et højere Forum i Berlin at afgøre, om de militære Anlæg var saa vigtige, at ernæringsmæssige Hensyn maatte vige, da heller ikke han var kompetent til at udtale sig herom. Man maatte imidlertid forelægge alle de farlige Konsekvenser, som Programmet indebar, for dette højere Forum. Vedrørende Brændselsstofproduktionen udtalte Dr. Walter, at man fra tysk Side lagde den allerstørste Vægt paa, 
at den danske Produktion blev størst mulig. Ingen kunde vide, hvorledes det i Fremtiden vilde gaa med Kulleverancerne, selvom de rent momentant synes at være relativt gunstige, men der laa en stor tysk Interesse $i$, at Danmark kunde forsyne sig selv i saa vid Udstrækning som muligt. En Borttrækning af Arbejdskraft fra Landbruget vilde iøvrigt i høj Grad gaa ud over det Program, som man fra tysk Side havde lagt Vægt paa, at Danskerne gik ind for, nemlig en udvidet Pro-

Noter

1 Det var ikke overraskende, at Best talte fransk, da han havde været ansat i den tyske besættelsesadministration i Frankrig 194042.

2 Martin Luther var leder af Abteilung Deutschland i Auswärtiges Amt og fra 1941 understatssekretær. I februar 1943, altså kort før denne optegnelse, blev han fjernet fra posten og indsat i koncentrationslejr for at have konspireret mod udenrigsminister Joachim von Ribbentrop.

3 Best tager her munden alt for fuld. Hans øverste foresatte var Joachim von Ribbentrop, hvis ordrer han skulle følge. Når han alligevel følte sig så selvsikker på dette tidspunkt, skyldtes det, at han nød SS-rigsfører Heinrich Himmlers positive bevågenhed og regnede med i givet fald at kunne vende tilbage til en stilling i SS, hvor han tidligere havde været ansat på en højt betroet post i en lang årrække. duktion af Rodfrugter navnlig Kartofler, som er stærkt arbejdskrævende. Dr. Walter udtalte, at Statsminister Scavenius under hans Ophold heroppe havde fremdraget alle disse Punkter overfor ham, og Dr. Walter havde fuldt ud forstaaet Situationens Alvor, og havde som sagt lovet at forelagge Problemet for en højere Instans i Berlin. Alt ialt havde man Indtrykket af, at man fra tysk Side fuldt ud indsaa Situationens Alvor.

4 DNSAP havde april 1941 etableret stabskontorer på Østerbro i København med henblik på den kommende politiske udvikling, mens partiets hovedkontor forblev $\mathrm{i}$ Bovrup. Stabskontorerne Rosenvængets Allé 30 og 32 blev opgivet 1. april 1943.

5 Samtalen med dr. Hans Dräger, bl.a. præsident for Nordische Verbindungsstelle og ansat i det tyske udenrigsministerium, havde Larsen refereret i dagbogen 14. januar 1941.

6 K.B. Martinsen var vidt fremme med forberedelsen til oprettelse af Schalburgkorpset. Han var leder af Frikorps Danmark.

7 C.F. von Schalburg, medlem af DNSAP og tidligere leder af Frikorps Danmark, var faldet i kamp på østfronten 2. juni 1942. Best havde ingen førstehåndsviden om ham, endsige viden om hans politiske ambitioner.

8 Af prestigemæssige grunde støttede besættelsesmagten Fadrelandet økonomisk til maj 1945. 